\title{
THE ROLE OF MEDIA DURING CONFLICTS
}

Alexander Chaevich,

Russian University of Transport, Russia

Vladislav Shirshikov,

Russian University of Transport, Russia

\begin{abstract}
Nowadays due to the unsettled political situation mass media is often used as a tool to gain power over public's consciousness. The functions of media therefore are more focused on the creation or interpretation of reality rather than on its reflection. The authors of the article have defined key roles of mass media during the conflict escalation.
\end{abstract}

Keywords: media, conflicts, escalation.

\section{Introduction}

The current state of most countries is usually described in terms of the information society, which is characterized by the impact of the intensification of information processes on the political, socio-economic and cultural development of society. In the information and communication 'space', mass media acquire additional opportunities for influence that can be implemented in both stable and unstable political conditions. However, the analysis of media functioning in situations of conflict interaction is of particular interest. Professor of International Communication Eytan Gilboa notes that the role of media in contemporary international conflicts is becoming more and more significant [8]. 


\section{Main part.}

As a necessary component of the system of information institutions in a society, media cannot fail to be one of the most significant actors when a conflict occurs. Moreover, political media discourse (despite its apparent virtuality) very often becomes the most real platform for conflict deployment and escalation.

However, before moving on to the role of media in conflicts it is essential to define such term as 'conflict'.

Lewis Kozer proposed a generally accepted definition of a conflict that is suitable for both political and social. According to him, conflict is a 'struggle for values, for a certain social status, power, material goods; and in this struggle opposing parties try to neutralize, damage, or destroying the enemy' [6].

Svetlana V. Denisenko [7] identifies several components of a conflict:

- presence of at least two parties;

- presence of a 'deficit", i.e., a limited number of material or spiritual goods ( not everyone can satisfy their needs);

- the parties seek to achieve their own goal (or to gain benefit)

- every effort is made to eliminate, or at least put under control the opposite party;

- power by which one can control the behavior of the other party.

Conflict escalation, in its turn, means increasing the intensity of the conflict.

Nowadays, a huge flow of information is being poured on the society. Every day, humans are forced to make many decisions. Due to the information given in a certain way, people do not think about the nature of their decisions and actions, being confident that these decisions are based on their own desires and beliefs. . 
It is journalists who can be both peacemakers during a conflict and instigators of conflict. It is obvious that the main task of the media in the context of conflict situations is to provide information promptly. It is information that becomes the main factor in shaping public opinion.

According, to researcher Medovkina [9], in this case the main activities of the media should be:

prompt dissemination of reliable, complete and objective information about activities during an armed conflict;

- preparation and dissemination of ready-made information, reference and explanatory materials in the media with the purpose of promotion of information in which a certain state is interested;

- $\quad$ assessment of the society reaction to the activities of a state (or e.g. state members) during a political (armed) conflict;

organization of strategic and operational interaction with the media and its representatives.

The functions of the media during armed conflicts can be the following:

- $\quad$ informing the audience;

- $\quad$ presentation of "entertainment" information for the audience;

- $\quad$ imposing on the audience the certain views of those who stand behind the media (owners or advertisers, for example), which reprograms recipient behavior in the direction that is needed.

While examining the peculiarities of media functioning during conflict situations a scholar Alyona S. Savitskaya points out that media very often facilitates shaping public opinion while it covers conflicts and fulfils people's need in receiving socially valuable information [12].

One may distinguish two types of information support during the conflict by media: purposeful or spontaneous coverage of significant events of the conflict [2]. According to some researchers, it is advisable to separate the concepts of spontaneous coverage and information support since the second 
one implies a much deeper involvement of the media in the conflict [3]. Coverage of the conflict can be understood as informing the audience, providing it with information about the conflict, its occurrences, its actors competing parties, their goals and intentions, about the possible consequences and results of a conflict situation.

Contribution of media coverage of the conflict to the shaping of public opinion can be viewed in the following way: media satisfies people's need to obtain socially significant information $[3 ; 4 ; 5]$, and therefore it contributes to the emergence of public opinion as a phenomenon. Often the media play the role of direct or indirect participants in the conflict by providing information support to the conflict situation.

In his book the analyst of the Center for Journalism in Extreme Situations of Russian Union of Journalists M. Melnikov identifies two types of conflict information coverage by media which oppose to each other [10].

The first one is called positive (or i.e. ideal) which is usually associated with information coverage (i.e. support) of the final de-escalation of the conflict. In this situation activities of a journalist, who is covering the conflict, should lead to a decrease in tension and in intensity of conflict confrontation.

Melnikov distinguishes certain principles on which this type of information support is based [10]:

- reflection and description of the true problems that caused the conflict;

- $\quad$ realistic assessment of the conflict stage;

- formation of an objective image of the parties of the conflict, absence of stereotypes;

presentation of a full retrospective of the conflict using alternative sources;

accurate and comprehensive coverage about conflict events; 
- reflection of all existing initiatives and steps to conflict resolution, support for social technologies to mitigate the conflict.

The second type of conflict information coverage is called negative and is aimed at increasing the tension of the conflict situation. It includes:

- demonstration of imaginary / false problems of the conflict;

- false assessment of the conflict stage;

- creating a false image of the conflict subjects, emphasis on negative stereotypes of one side and positive stereotypes of the opponent;

- $\quad$ presenting a selective retrospective of the conflict, refusal to use alternative sources;

- $\quad$ biased informing about conflict events;

- selective reflection of initiatives, decisions and actions of opponents to resolve the conflict; support of actions and initiative that are aimed at escalating the conflict.

Richard C. Reuben agrees upon the idea that news coverage of conflict may contribute to constructive or destructive outcomes of those disputes [13].

Savitskaya points out that media input into conflict escalation should not be evaluated only as negative, as conflict escalation can reveal the true intentions of the opposing parties, clearly identify the motives, interests and values of the actors, increase the significance of the problem, and attract the attention of public institutions that can assist in conflict resolution [12].

However, very often in a situation of conflict information wars [11] can unfold in the media space.

Information (or sometimes information-psychological) war has historically been part of a real war or a confrontation. Nowadays, it is seen as a destabilizing factor in the establishment of international relations and generates real political or even military conflicts. 
During information war competitors distribute a variety of prompt (relying on effect of primacy), frequent (relying on the impact of frequent messages), and a combination of true or fake news products. This news is filled with details and various arguments, and with both negative and positive conclusions (key messages) from a variety of popular sources with different levels of reliability. This has become a good basis for the prosperity of fake news which are often seen as political media products that are similar in form (genre, composition, style) to classic news, are perceived as reliable messages, but which are created by actors without supporting facts or evidence. It is an element of information wars in the storytelling format.

\section{Conclusion}

Information tempering may be used by certain parties by means of media during information wars that tend to exploit all the opportunities and vulnerabilities that inevitably arise from increasing dependence on information, as well as use information itself in conflicts [1].

Nowadays, media plays a crucial role: media sources provide people with information, highlighting certain facts, details and occurrences, and hence shapes recipient's opinion about the conflict. Out of the countless events, conflicts and problems of reality, mass media can either hide unpleasant facts of any events or, on the contrary, make up such facts in the absence of accurate information, choose only some facts while deliberately ignoring the others. At the same time, the selected facts are given artificial 'authenticity' [13; 14] and 'significance' and can be often served 'dosed', in small portions, but with repetitions. It should be noted that this selective coverage simplifies the occurrences and creates basis for speculation.

Such possibilities and functions of media may turn it into participants of a conflict. Depending on which communication tools, strategies, tactics, media 
chooses, and how objective or subjective the material about the event is presented, media can transform a small conflict into a large-scale war, or divert attention from the problem and reduce the level of confrontation or event stop the conflict. In most cases the presentation of the material determines the course of the conflict. At first reality goes through the lens of mass media and only then it appears before the audience in the form of news articles, radio or TV reports, expert opinions, etc. All this together forms a media picture of reality, which becomes basically an interpretation. That is why media has become a significant influencer in conflict situations. The problem, however, that there are fewer and fewer independent media, which becomes a fuel of development of information wars, since media starts to express opinion of those who stand behind it, and not an objective opinion.

Nonetheless, media should strive to provide objective coverage of information by referring to independent experts, carefully and thoroughly study processes, present events as it is the facts covered by the media that foster developing a certain reaction from citizens.

\section{References}

1. Marwick A. E., Lewis R. (2012). Media manipulation and disinformation Online. New York: Data and Society Research Institute. Retrieved from: https://essaybasics.com/files/writing-guides/APA\%206th\%20ed.pdf

2. Bennett, W. L., \& Livingston, S. (2018). The disinformation order: Disruptive communication and the decline of democratic institutions. European Journal of Communication,33(2). Retrieved from https://journals.sagepub.com/doi/10.1177/0267323118760317

3. Kaminskaya, T.L. (2019) Political Media Texts and The Problem of Confidence: Modern Challenges. Humanities. Bulletin of the Financial 
University,

https://cyberleninka.ru/article/n/politicheskie-mediateksty-i-problemadoveriya-covremennye-vyzovy

4. Harsin, J. (2018) A Critical Guide to Fake News: From Comedy to Tragedy. Pouvoirs, 164. Retrieved from https://www.cairn-int.info/article-E POUV 164 0099--a-critical-guide-tofake-news-from.htm

5. McIntyre, L. (2018). Post-truth. Cambridge: The MIT Press.

6. Kozer, L. (2000) Functions of social conflict. Moscow: Idea press.

7. Denisenko, S.V. (2019). Modern political armed conflicts and ways of their safe resolution. Bulletin of the Law Faculty, 6 (4). Retrieved from: https://cyberleninka.ru/article/n/sovremennye-politicheskie-vooruzhennyekonflikty-i-puti-ih-bezopasnogo-razresheniya/viewer

8. Gilboa, E. (2007). Media and International Conflict: A Multidisciplinary Approach. Journal of Dispute Resolution, 2007 (1). Retrieved from

https://scholarship.law.missouri.edu/cgi/viewcontent.cgi?article=1533\&cont $\underline{\text { ext }=\mathrm{jdr}}$

9. Medovkina, L.J. (2016). The Media Influence on Armed Conflicts. Scientific Bulletin of the Belgorod state University. Series: History. Political $\begin{array}{lllll}\text { science, } & 40 & (22 & \text { (243) }) . & \text { Retrieved }\end{array}$ https://cyberleninka.ru/article/n/sovremennye-politicheskie-vooruzhennyekonflikty-i-puti-ih-bezopasnogo-razresheniya/viewer

10. Melnikov, M. (2006). Applied conflictology for journalists. Moscow: Human rights.

11. Pocheptsov, G.G. (2001). Information wars. Moscow: Refl-buk.

12. Savitskaya, Alyona (2011). Mass media in social conflicts. Izvestiya Rossiyskogo gosudarstvennogo pedagogicheskogo universiteta im. A. I. Gerzena, (92). Retrieved from: 
https://cyberleninka.ru/article/n/sredstva-massovoy-informatsii-v-situatsiikonfliktnogo-vzaimodeystviya

13. Reuben, R. C. (2009).The Impact of News Coverage on Conflict: Toward Greater Understanding. Marquette Law Review, 93(1). Retrieved from: http://scholarship.law.marquette.edu/cgi/viewcontent.cgi?article=4926\&con $\underline{\text { text }=\text { mulr }}$

14. Dobrosklonskaya, T. G. (2014). Mass media discourse as an object of scientific description. Scientific Bulletin of the Belgorod state University. Series: Humanities, 22 (13 (184)). Retrieved from: https://cyberleninka.ru/article/n/massmediynyy-diskurs-kak-obektnauchnogo-opisaniya 